\title{
The Effect of Pension Accounting on Corporate Pension Asset Allocation
}

By

Eli Amir*

London Business School

Regent's Park

London NW1 4SA

eamir@london.edu

Yanling Guan

School of Business

The University of Hong Kong

ylguan@business.hku.hk

Dennis Oswald

Ross School of Business

University of Michigan

Ann Arbor, MI 48104

denniso@umich.edu

August 2008

*Corresponding author. We thank Katherine Schipper (Editor), Anonymous Reviewer, David Blake, Elroy Dimson, John Pickles, Laurens Swinkels, Richard Taffler and seminar participants at the 2008 CAR\&E conference, INSEAD, University of North Carolina, Tel Aviv University and University of Warwick for many useful comments. We also thank London Business School's research funding for this project. Address correspondence to Eli Amir, London Business School, eamir@london.edu 


\title{
The Effect of Pension Accounting on Corporate Pension Asset Allocation
}

\begin{abstract}
We examine the impact of new pension disclosures and subsequent full pension recognition under FRS 17 and IAS 19 in the UK and SFAS 158 in the US on pension asset allocation. These standards require recognition of the total pension surplus/deficit on the balance sheet and periodical actuarial gains/losses in shareholders' equity. Therefore, these standards introduce a large element of volatility into company balance sheets and comprehensive income.

We identify a Disclosure period during which UK companies had to disclose all the required data under FRS 17 in the notes without formal recognition. We also identify a Full Recognition period starting one year prior to until one year subsequent to the adoption of FRS 17/IAS 19 (UK) and SFAS 158 (US). We predict a shift of pension assets from equity to debt securities by UK companies during the Disclosure period due to the higher visibility of pensions in the UK and the anticipation of full recognition. We also predict a decline in pension funds allocated to equity securities during the Full Recognition period, around the adoption of FRS 17/IAS 19 and SFAS 158.

We find that UK companies, on average, shifted pension assets from equity to debt securities during both the Disclosure and the Full Recognition periods. We also find that while prior to the adoption of SFAS 158 US companies maintained a stable allocation to equities and bonds, these companies, on average, shifted funds from equities to bonds around the adoption of $S F A S$ 158. Cross-sectional analysis shows that the shift away from equities is related to changes in funding levels, shorter investment horizons, increased financial leverage and the expected impact of the new standards on shareholders' equity.
\end{abstract}

Keywords: Defined Benefit Plans, Pension Asset Allocation, Pension Surplus/ Deficit, FRS 17, IAS 19, SFAS 158. 


\section{Introduction}

We investigate the effect of new pension disclosures and subsequent recognition requirements of pension surplus/deficit on the allocation of pension funds to equity and debt securities. In November 2000, the Accounting Standards Board $(A S B)$ in the UK issued Financial Reporting Standard (FRS) No. 17, Retirement Benefits ( $A S B$, 2000), which initially had to be adopted in June 2003. In 2002, $A S B$ extended the transitional period of FRS 17 to fiscal years starting on or after January 2005, which coincided with the adoption of International Financial Reporting Standards (IFRS) in Europe. Effectively, UK companies had to adopt the revised International Accounting Standard (IAS) No. 19 (IASB, 2004), which was virtually identical to FRS 17. In September 2006, the Financial Accounting Standard Board (FASB) issued SFAS 158 (FASB, 2006), which replaced SFAS 87 (FASB, 1985) and became effective for all US companies in December 2006.

Between fiscal 2000 and the adoption of FRS 17/IAS 19, UK companies had to provide new and detailed disclosure on the status of their pension plans. Adoption of FRS 17/IAS 19 implies that UK companies recognize the total pension surplus/deficit on the balance sheet (net of deferred tax). Any resulting actuarial gains or losses arising during the year are recognized immediately in shareholders' equity. Similarly, SFAS 158 requires full recognition of the pension surplus/deficit on the balance sheet and immediate recognition of all actuarial gains/losses and prior service cost through other comprehensive income.

The recognition of net pension surplus/deficit as an asset/liability on the balance sheet and actuarial gains/losses in shareholders' equity under FRS 17/IAS 19 and SFAS 158 introduce material volatility to balance sheets of UK and US companies, especially if pension assets are mostly invested in equity securities. In particular, reporting actual, rather than smoothed, pension returns injects volatility into shareholders' equity while the recognized net pension asset/liability could be a significant portion of a company’s book 
value and market capitalization. ${ }^{1}$

A cost-effective way of reducing the volatility of the pension deficit/surplus and the volatility of comprehensive income and shareholders' equity is matching pension assets with pension liabilities. This could be achieved by selecting a portfolio of pension assets whose fair value is more positively correlated with the fair value of the pension liability, namely bonds. ${ }^{2}$ Alternatively, companies could react to the new accounting rules by terminating pension plans (Klumpes and Whittington, 2003) or by converting defined benefit pension plans into defined contribution and cash balance plans (D’Souza et al., 2004; Swinkels, 2006). However, these actions may be costly due to tax and labor negotiation costs.

We examine the impact of new pension disclosures and full pension recognition on asset allocation of UK and US companies. In particular, we examine changes in UK companies' pension asset allocation before and after the adoption of FRS 17/IAS 19 (2000-2007). We identify two distinct accounting regimes for UK companies: A Disclosure period ranging from fiscal 2001 until one year prior to the adoption of FRS 17/IAS 19, and a Full Recognition regime, starting from one year prior to adoption until one year after the adoption of FRS 17/IAS 19. We predict that UK companies that sponsor defined benefit pension plans will shift pension assets from equity to debt securities during the Disclosure period. This is because of the increased visibility of pension plans due to market-based disclosures and the anticipation of the effect of full pension recognition on the volatility of shareholders' equity and comprehensive income. We also predict a decline in pension assets allocated to equity securities during the Full Recognition period due to the recognition of pension surplus/deficit on the balance sheet and the higher anticipated volatility of shareholders' equity and

\footnotetext{
${ }^{1}$ The volatility that can be introduced into corporate balance sheets is evidenced by the fact that at the end of 2001 the combined surplus for the FTSE 100 was $£ 5$ billion, but by mid July 2002 with the collapse in world stock markets this fell to a deficit of $£ 25$ billion (Reynolds, 2002).

${ }^{2}$ A report by the Committee on Investment of Employee Benefit Assets has estimated that switching to markto-market pension accounting would result in approximately \$290bn in funds being shifted from equities to bonds (Brewsterin, 2005).
} 
comprehensive income. We also examine whether full recognition pension accounting under SFAS 158 prompted US companies to shift pension assets from equities to bonds. As US companies had to adopt Full Recognition accounting under SFAS 158 in 2006, we predict a decline in the allocation to equity securities by US companies from one year prior to the adoption of SFAS 158 (fiscal 2005) until one year after the adoption of the standard (fiscal 2007).

The new pension accounting standards in the UK and the US may not be the only reason for the change in the composition of pension assets. Contemporaneous changes in funding levels due to imposed minimum funding requirements, shorter investment horizons, changes in plan coverage and increased financial leverage could trigger similar asset allocation changes. Multivariate cross-sectional analysis reveals that while other factors have significant effects on pension asset allocation, the expected impact of the new standards is incrementally informative in explaining the shift to debt securities in UK and US companies; that is, the shift to debt securities is more significant in companies with larger pension schemes relative to shareholders' equity.

To test our hypotheses, we use pension asset allocation data for large UK and US companies over the period 2000-2007. Using a sample of 1,509 and 2,128 firm-year observations for UK and US companies, respectively, we find that during the FRS 17 Disclosure period, UK companies, on average, shifted funds from equity to debt securities. We also find that both UK and US companies shifted pension assets from equities to bonds during the Full Recognition period of FRS 17/IAS 19 and SFAS 158, respectively. This shift reduces the effect of the new standards on the volatility of shareholders' equity and comprehensive income. In addition, cross sectional tests show that UK and US companies for which the negative impact of full recognition was expected to be stronger shifted relatively more funds from equity to debt securities. Collectively, the results support the 
argument that new pension accounting standards in the UK and the US had a significant impact on corporate pension asset allocation, incrementally to other economic factors.

This study contributes to the literature in several ways. It examines the determinants of pension asset allocation in an international setting using both UK and US companies. In addition, it is conducted during a period of a pension accounting change in both the UK and the US, which is a powerful setting for our study. Furthermore, the empirical evidence in this study is important in understanding the possible effects of full recognition pension accounting on capital markets.

The remainder of this study is organized as follows. In section 2, we develop the hypotheses to be tested. Section 3 describes the research design. Sample selection and descriptive statistics are included in Section 4. Section 5 provides the empirical results while Section 6 provides concluding remarks.

\section{Hypotheses}

Following the issuance of $F R S 17$ in 2000, UK companies were required to disclose the present value of the pension obligation and the market value of pension plan assets, as well as actuarial assumptions and details on asset allocation. These new disclosures meant greater transparency of the pension scheme as well as increasing investor scrutiny of the impact of pension schemes on financial statements. While $F R S 17$ disclosures provide comfort to investors in over-funded plans, under-funded companies are perceived as riskier because pension deficits are a form of debt. ${ }^{3}$ Also, the existence of Minimum Funding Requirements increases the likelihood of additional pension contributions, especially in under-funded plans. Higher future pension contributions and the uncertainty associated with their timing and magnitude also increases the perceived risk of sponsoring companies. Furthermore,

\footnotetext{
${ }^{3}$ See Harris et al. (2001) for a discussion of the effects of FRS 17 on financial statements and valuation.
} 
under $F R S$ 17, employees have access to more accurate pension disclosures, which could trigger pressure to reduce plan risk, as the employees bear the deficit, while the company enjoys the surplus.

Thus, new pension disclosure requirements are potentially costly and companies would prefer to hedge themselves against potential pension deficits by reducing the volatility of the pension surplus/deficit and improving the matching of pension assets and liabilities (Blake, 2001). Better matching is achieved by allocating more pension assets to debt (i.e., bonds and other interest bearing securities) instead of equity securities. As the market value of bonds is generally less volatile than that of equities, and since pension liabilities largely depend on prevailing yield on bonds, such a policy would result in lower volatility of the pension deficit/surplus. In addition, a shift from equities to bonds is likely to be exacerbated by the anticipated adoption of $F R S 17$ and the recognition of the full pension liability on subsequent balance sheets. In contrast, shifting pension assets to bonds is likely to result in higher future pension contributions, as the expected rate of return on bonds is lower than that on equities. Thus, the shift from equity to debt securities will continue as long as the cost of reporting a pension deficit is higher than the present value of additional future contributions. This leads to our first hypothesis:

Hypothesis 1: UK companies that sponsor defined benefit pension plans will shift pension assets from equity to debt securities during the FRS 17 Disclosure period.

Adoption of FRS 17/IAS 19 in the UK and SFAS 158 in the US meant recognition of the entire pension deficit/surplus on the balance sheet, recognition of all prior service costs in net income and recognition of all actuarial gains/losses in comprehensive income. Therefore, in addition to increasing, on average, the amount of debt on the balance sheet, adoption of 
the new standards in both countries is expected to increase the volatility of shareholders' equity and comprehensive income.

Adoption of full pension recognition could have significant contractual implications. First, as many contracts are based on verifiable balance sheet figures, higher recognized debt on the balance sheet increases the likelihood of violating existing debt covenants, hence the cost of debt renegotiation. Second, higher volatility of shareholders' equity increases the probability of violating equity-based debt covenant because the balance sheet is now exposed to market volatility through interest rate changes and changes in market values of equities. Third, as the pension deficit is recognized against the company's distribution reserves, adoption of the new standards may decrease distributable reserves and may have a negative effect on the company's ability to pay dividends or to maintain a stable stream of dividends. Adoption could also have a negative effect on stakeholders' ability to evaluate management performance. For example, Return on Equity $(R O E)$, a widely used management performance measure, may be distorted as shareholders' equity becomes more volatile. If stakeholders consider comprehensive income in the numerator of $R O E$, then the volatility of $R O E$ is even higher. In addition, higher volatility of shareholders' equity and comprehensive income could create a perception of weaker management control. To mitigate the effect of adoption on existing contracts and to facilitate better performance evaluation, we expect companies to shift pension assets from equity to debt securities during the adoption of full pension recognition. This argument leads to our second hypothesis:

Hypothesis 2: UK and US companies that sponsor defined benefit pension plans will shift pension assets from equity to debt securities during the Full Recognition period (adoption of FRS 17/IAS 19 in the UK and SFAS 158 in the US). 
The impact of the new pension standards is expected to be more (less) significant in companies with relatively larger (smaller) pension plans. For example, in its 2003 annual report, Charter Plc, a UK-based engineering company, reported pension assets with a market value of £462.2 million, while its shareholders' equity amounted to £24.9 million. This means that a decline of $5.4 \%$ in the market value of pension assets could eliminate the company's entire shareholders' equity restricting its dividend payout ability. Similarly, a decline in the yield on the AA-rated corporate bonds could eliminate shareholders' equity, as the pension obligation increases when the discount rate declines. Thus, we expect companies with larger pension schemes relative to shareholders equity to shift more assets from equity to debt securities during the Disclosure and Full Recognition periods. ${ }^{4}$

Companies with larger pension schemes also experience larger actuarial gains/losses, especially if a majority of pension assets are invested in equity securities. These companies are more sensitive to the volatility effects of the new standards and would therefore have stronger motivation to shift pension assets from equity to debt securities. In contrast, companies with smaller actuarial gains/losses would have a weaker motivation to switch pension funds to debt securities, since shifting to less risky assets also implies a lower expected return on pension assets on the income statement (Fernandez, 2002). Consequently, we hypothesize that the shift from equity to debt securities will be more significant for companies with a larger ratio of pension assets/liabilities to shareholders' equity. We expect this relation for UK companies during both the Disclosure and Full Recognition periods and for US companies during the Full Recognition period.

\footnotetext{
${ }^{4}$ In 2001, Boots plc. liquidated all of its equity holdings in its $£ 2.3$ billion pension fund and moved the proceeds into long-dated bonds (Ralfe, 2002; McLeish, 2001). Similarly, General Motors reduced the share of equities in the pension portfolio from $47 \%$ in $12 / 2005$ to $38 \%$ in $12 / 2006$ and to $26 \%$ in 12/2007.
} 
Hypothesis 3a: The shift of pension assets from equity to debt securities by UK companies during the Disclosure period is positively correlated with the relative size of the pension scheme.

Hypothesis 3b: The shift of pension assets from equity to debt securities by UK and US companies during the Full Recognition period is positively correlated with the relative size of the pension scheme.

While this study highlights the asset allocation effects of new pension accounting standards, other factors may have material allocational effects during the Disclosure period in the UK and the Full Recognition period in the UK and the US. Prior literature identifies three major factors that affect pension asset allocation: Funding levels, investment horizon and offsetting firm risk. ${ }^{5}$

Both UK and US companies are subject to Minimum Funding Requirements (MFR). For example, in August 2006, the Pension Reform Act was signed into law in the United States. This Act requires defined benefit pension plans to attain full funding status within seven years by contributing funds to the plans. These requirements are expected to increase funding levels over time. Prior literature is rather mixed as to the effect of funding levels on asset allocation. Still, Harrison and Sharpe (1983) suggest that as pension plans become less underfunded, the allocation to equities should decline. Thus, increasing funding levels could trigger a decline in the allocation to equities independent of new accounting standards. Investment maturity could also have a significant effect on asset allocation. As pension plans become more mature, the investment horizon is shortened, which is expected to trigger a shift of pension assets from equities to bonds. Finally, prior studies documented a negative

\footnotetext{
${ }^{5}$ Black (1980), Feldstein and Seligman (1981), Tepper (1981) and Harrison and Sharpe (1983), among others.
} 
relation between firm risk and the allocation to equities, as companies offset firm risk by using a more conservative pension asset allocation policy. Therefore, a change in pension asset allocation could be associated with changes in firm risk and not necessarily related to new accounting standards. Although our main empirical focus is on the impact of the new accounting standards, we do control for these alternative 'economic' explanations in our empirical tests.

\section{Empirical Design}

Pension assets are classified in the notes to the financial statements into three main categories: 'stocks', 'bonds', and 'other'. Stocks and bonds together account for about 90\% of total pension funds in our UK and US samples. 'Other' often includes assets such as mortgage-backed securities, venture capital, private placement, properties, etc.

To test hypotheses 1 and 2, we analyze pension asset composition over the period 20002007 for a sample of UK and US companies. Specifically, we test whether UK companies have shifted pension funds from equities to bonds during the Disclosure period and the Full Recognition period, and whether US companies shifted funds from equities to bonds during the Full Recognition periods. We also examine whether funding levels, investment horizon and firm risk changed systematically over the sample period.

To test hypotheses $3 \mathrm{a}$ and $3 \mathrm{~b}$, we construct a model that explains the cross-sectional variation in the percentage of pension funds allocated to equity securities ( $\left.r E Q U I T Y_{i t}\right)$ :

$$
\begin{aligned}
& r E \text { UITY }_{i t}=\beta_{0}+\beta_{1} I_{M P A C T_{i t}}+\beta_{2} \text { FUND }_{i t}+\beta_{3} \text { FUND }_{i t}^{2}+\beta_{4} H O R_{i t}+\beta_{5} L E V_{i t} \\
& +\beta_{6} \text { DIVP }_{i t}+\beta_{7} \text { TAXR }_{i t}+\beta_{8} \text { SDCF }_{i t}+\beta_{9} S I Z E_{i t}+\beta_{10} C L O S E_{i t}+\varepsilon_{i t}
\end{aligned}
$$

The dependent variable in Equation (1), $r E Q U I T Y_{i t}$, is the market value of pension assets allocated to equity securities divided by the market value of total pension assets for 
firm $i$ in year $t$. The first independent variable in Equation (1) is $I M P A C T_{i t}$, which measures the potential impact of the new accounting standards on company $i$ in year $t$. As the impact relates primarily to the relative size of the pension plan, we use two simple measures of the size of the pension plan relative to shareholders' equity:

(i) EXPOS1 $1_{i t}$ : The fair value of pension assets deflated by book value of shareholders' equity. This variable captures the company's exposure to the volatility in the market value of pension assets and net pension surplus/deficit.

(ii) EXPOS2 $2_{i t}$ : The Projected Benefit Obligation $(P B O)$ deflated by book value of shareholders’ equity. This variable captures the company’s exposure to the volatility in discount rates.

To compute $E X P O S 1_{i t}$ and EXPOS2 ${ }_{i t}$, we use shareholders' equity before the effect of actuarial gains/losses and the recognition of net pension surplus/deficit.

Tax and regulatory factors play a significant role in asset allocation through funding levels. In general, the tax-deductibility of pension contributions should induce companies to pre-fund their pension plans; companies that are subject to higher tax rates should have even greater incentives to pre-fund their plans. Black (1980) and Tepper (1981) argue that since returns on pension assets are not taxed, these assets should be invested in the most heavily taxed securities, presumably bonds. Their argument suggests no association between funding levels and asset allocation as all companies invest in bonds regardless of funding levels. In contrast, Harrison and Sharpe (1983) argue that the existence of the Pension Benefit Guaranty Corporation ( $P B G C$ ) provides US companies with a put option on extremely under-funded pension obligation. Together with limited tax deductibility in the case of extremely over-funded plans, they argue that funding and asset-allocation decisions are joint and extreme. To maximize tax benefits on one hand and the value of the $P B G C$ option on the other hand, companies should either over-fund the pension plan and allocate all the assets to 
bonds, or under-fund and allocate all the assets to equities. Although in practice funding/asset-allocation decisions are rarely extreme, this argument supports a negative relation between funding levels and allocations to equities. A serious caveat is that the value of the $P B G C$ put option in the US has declined over time and in particular since the 1986 Tax Reform Act. Also, an insurance company such as the $P B G C$ did not exist in the UK until 2006. Therefore, the incentive to allocate pension assets to equities in cases of extreme under-funding may be of a second order nature.

Bader (1991) argues that companies strive to minimize the volatility of future pension contributions. These contributions are fairly predictable for moderate funding levels, but less predictable for more extreme levels. To reduce the volatility of pension contributions, he argues that extremely over-funded and under-funded plans should invest in bonds, while only moderately funded plans should increase allocation to equities. His argument suggests an inverted U-shape relation between funding levels and the allocation to equities.

Based on these arguments, we include both $F U N D_{i t}$ and $F U N D^{2}{ }_{i t}$ to accommodate the possibility of a non-linear relation between funding levels and allocation to equities. ${ }^{6}$ The funding status is measured as the fair value of pension assets divided by the accumulated benefit obligation $(A B O)^{7}$

Investment horizon plays a significant role in pension asset allocation. While pension obligations to retirees are relatively short-term and are primarily affected by interest rates, obligations to active employees are relatively long-term and are primarily affected by salary increases. As bonds are more correlated with interest rate changes and stocks are more highly correlated with salary increases, companies with relatively young (mature) workforce should invest more in stocks (bonds). Consequently, we expect a positive correlation

\footnotetext{
${ }^{6}$ Amir and Benartzi (1999) documented an inverted-U relation between funding status and the percentage invested in equities.
} 
between investment horizon, $H O R_{i t}$, and allocation to equities. $H O R_{i t}$, is measured as the natural logarithm of the ratio of $P B O$ to current service cost. Overall, an older (younger) workforce should lead to a smaller (larger) ratio of $P B O$ to service cost, indicating a shorter (longer) investment horizon.

Our horizon variable $\left(H O R_{i t}\right)$ may be subject to measurement error. To mitigate this problem, we include another variable that is associated with investment horizon. This variable, $C L O S E_{i t}$, takes into account recent trends to move away from defined benefit to defined contribution pension plans and close the defined benefit plans to new entrants (McSherry, 2006). Thus, we include in our model an indicator variable that is equal to one if the principal defined benefit plan is closed to new entrants, and zero otherwise. As the investment horizon of closed plans is, on average, shorter, we expect a negative relation between this variable and allocations to equities.

Our model also includes variables that capture the influence of debt contracts and dividend payout policy. As the pension surplus/deficit is recognized on the balance sheet, the pension asste/liability and corresponding investment portfolio may be affected by certain contractual arrangements. In particular, companies that are closer to the violation of debt covenants have stronger motives to improve asset/liability matching in order to reduce recognized pension deficits. Better asset/liability matching would also reduce the volatility of shareholders' equity and future pension contributions, which in turn would reduce the volatility of dividends. We expect companies with tighter debt covenants and higher dividends payout ratios to allocate more to bonds. To capture these effects, we include financial leverage $\left(L E V_{i t}\right)$ and dividends payout ratio $\left(D I V P_{i t}\right)$. We expect the coefficients on these variables to be negatively associated with the amount invested in equity. Financial

\footnotetext{
${ }^{7}$ Since ABO is not available for UK companies, we calculate ABO based on the formula proposed in Amir and Benartzi (1999): $A B O=P B O /(1+\mathrm{G})^{\mathrm{N}}$, where $\mathrm{G}$ is the assumed projected salary increase and $\mathrm{N}$ is pension fund's investment horizon.
} 
leverage $\left(L E V_{i t}\right)$ is, measured as long term debt divided by the sum of long term debt and market value of equity for firm $i$ in year $t$. Dividend payout ratio $\left(D I V P_{i t}\right)$ is measured as dividends per share divided by retained earnings per share. If retained earnings are negative, then the variable is measured as the average dividends per share over the current and past two years divided by average retained earnings per share over the current and past two years.

Companies subject to higher tax rates should have greater incentives to allocate more pension assets to bonds, as bonds are more heavily taxed. Therefore, we include the company's effective tax rate $\left(T A X R_{i t}\right)$, measured as total tax expense divided by pre-tax income in year $t$. If current pre-tax income is negative, we use the average tax expense over the current and past two years divided by the average pre-tax income over the current and past two years.

Friedman (1983) and Bodie et al. (1984) find that companies offset high corporate risk by investing more of the pension assets in bonds. This policy of offsetting risk through the pension fund may reflect management preference to avoid making contributions to the pension fund when operating cash flows are low. ${ }^{8}$ Consistent with these findings, we expect a negative correlation between the variability of operating cash flows and equity allocation. In addition, companies with more diversified operations would prefer to assume more risk in their pension fund. To the extent that larger firms are more diversified, we would expect a positive association between firm size and allocation to equities. The volatility of operating cash flows $\left(S D C F_{i t}\right)$ is measured as the standard deviation of operating cash flows over the current and past four years, deflated by book value of common equity. Firm size $\left(S I Z E_{i t}\right)$ is measured as the natural logarithm of market value of equity.

To directly test our hypotheses, we define two dependent variables: The first one

\footnotetext{
${ }^{8}$ Specifically, if operating cash flows are volatile and the pension assets are invested in equities, the plan is likely to become under-funded when operating cash flows are low. As a result, the company would have to make large contributions to the pension fund in times of low operating cash flows.
} 
computes the change in the percentage of assets allocated to equities during the Disclosure period of UK companies. The Disclosure period is defined as the period between fiscal 2001 and the year before the adoption of FRS 17/IAS 19:

$$
r D I S C L O S E=r E Q U I T Y\left(\text { year 2001) }-r E Q U I T Y(\text { Pre-Adoption year })^{9}\right.
$$

The second dependent variable computes the change in percentage of assets allocated to equities during the Full Recognition period. For UK (US) companies, this period begins one year prior to adoption of $F R S 17 / I A S 19$ (SFAS 158) and ends one year subsequent to adoption:

$$
r A D O P T=r E Q U I T Y \text { (Pre-Adoption year) - rEQUITY (Post-Adoption year). }
$$

We estimate Equation (2) for UK companies only. The independent variables are measured as the difference between the level of the variable at the beginning of the Disclosure period and its level at the end of the period.

$$
\begin{aligned}
& \text { rDISCLOSE }{ }_{i}=\beta_{0}+\beta_{1} \Delta I M P A C T_{i}+\beta_{2} \Delta F U N D_{i}+\beta_{3} \Delta F U N D_{i}^{2}+\beta_{4} \Delta H O R_{i} \\
& +\beta_{5} \Delta L E V_{i}+\beta_{6} \Delta \operatorname{DIVP}_{i}+\beta_{7} \Delta \operatorname{TAXR}_{i}+\beta_{8} \Delta S D C F_{i}+\beta_{9} \Delta \operatorname{SIZE}_{i}+\beta_{10} \Delta C L O S E_{i}+\varepsilon_{i t}
\end{aligned}
$$

In addition, we estimate Equation (3) for both UK and US companies around the Full Recognition period. To control for long-term asset allocation trends, we added to Equation (3) another control variable, rDISCLOSE, which captures asset allocation changes prior to adoption. Controlling for prior allocational effects could allow us to draw more accurate inferences on the incremental effect of accounting standards on pension asset allocation.

\footnotetext{
${ }^{9}$ Technically, the Disclosure period begins in year 2000. However, we use 2001 as the starting year because many observations for year 2000 are missing.
} 
$r A D O P T_{i}=\delta_{0}+\delta_{1} \Delta I M P A C T_{i}+\delta_{2} \Delta F U N D_{i}+\delta_{3} \Delta F U N D_{i}^{2}+\delta_{4} \Delta H O R_{i}$

$+\delta_{5} \Delta L E V_{i}+\delta_{6} \Delta D I V P_{i}+\delta_{7} \Delta T A X R_{i}+\delta_{8} \Delta S D C F_{i}+\delta_{9} \Delta S I Z E_{i}+\delta_{10} \Delta C L O S E_{i}$

$+\delta_{11} r$ ISCLOSE $E_{i}+\eta_{i}$

The independent variables in Equation (3) are measured as the difference between the level of the variable before and after adoption.

We use ordinary least square (OLS) to estimate the above equations. Petersen (2008) argues that residuals may be correlated across firms or across time in panel data and therefore $O L S$ standard errors may be biased. In this study, it is possible that the unspecified determinants of the dependent variables are correlated both over time and across firms. For example, if the equity market as a whole is volatile, then all firms may shift away from volatile equities to less volatile bonds. On the other hand, the strategy of pension asset allocation could also be driven by some unspecified firm-specific factors, which will give rise to a firm effect in the error terms. The presence of positive correlation among error terms results in underestimated standard errors and thus inflated $t$-statistics. To address such econometric concern, we employ two-dimension clustering suggested by Petersen (2008) to accommodate the possibility of both time effect and firm effect in such panel data.

\section{Sample Selection and Descriptive Statistics}

The initial UK sample contains 250 companies that belong to the FTSE 350 list and that sponsor defined benefit pension plans during 2000-2007. We deleted from the UK sample seven companies that elected the "corridor" method allowed under IAS 19. Information on market value of pension assets, actuarial present value of pension liabilities, pension actuarial assumptions, actuarial gains/losses and details of pension asset allocation 
are collected from annual financial statements. All other financial data for UK companies are from Datastream.

Data for US companies' pension asset allocation until 2004 are collected from Pensions and Investments, a periodical survey that covers the largest 1,000 pension funds in the US. Of this 1,000 , approximately 300 pension funds relate to defined benefit plans for publicly traded firms (the remainder are sponsored by private firms, unions, or government entities, or are foreign companies listed in the US). Asset allocation data for 2005-2007 are collected from notes to the annual financial statements. Financial data for US companies are from Compustat. After removing observations with missing data, the sample consists of 4,440 firm-year observations, of which 1,509 observations are for UK companies and 2,128 observations are for US companies.

Table 1 provides descriptive statistics for the UK and US sub-samples. Over the entire sample period, both UK and US companies allocate, on average, $62 \%$ of their pension assets to equities. The size of the pension plan relative to shareholders' equity is larger in UK than in US firms, as reflected by higher means and medians of EXPOS1 and EXPOS2 (statistical tests not reported). This difference could lead to more significant allocational effects in the UK than in the US. As for other variables, the UK and US sub-samples are similar to each other in terms of funding status (FUND), pension horizon (HOR) and effective tax rates (TAXR). US companies are less risky as reflected by lower volatility of cash flows $(S D C F)$ and larger firm size (SIZE). US companies also have lower dividend payout ratios, for the median firm, and are more highly leveraged than UK companies. ${ }^{10}$

(Table 1 about here)

Most UK companies adopted IAS 19 in 2005, the mandatory year of adoption. However, 54 UK companies in our sample adopted FRS 17 prior to the mandatory year. 
Prior literature suggests that the timing of adoption of new accounting studies is largely affected by the impact of the new standard on the financial statements and by contracting costs (e.g., Amir and Ziv, 1997). Using logistic regressions to identify the characteristics of UK companies that elected early adoption of $F R S$ 17, we find (results not tabulated) that early adopters have, on average, smaller (at the 0.05 level) ratios of pension assets to shareholders' equity (EXPOS1). In addition, we find that early adopters have longer (at the 0.05 level) investment horizons (HOR). All other variables that were examined (rEQUITY, FUND, LEV, SIZE, CLOSE) were not significant (at the 0.10 level) in explaining the adoption decision. These results are consistent with the claim that UK companies that were less affected by FRS 17 were more likely to adopt the standard earlier.

Table 2 provides data on the composition of pension assets for UK companies (top panel), a sub-sample of 54 UK early adopters of FRS 17 (middle panel) and US companies (bottom panel) over 2000-2007. UK companies gradually decreased their average allocation to equities by $19.8 \%$ and increased their allocation to bonds by $12.7 \%$. UK early adopters of FRS 17 exhibit a similar pattern until 2003; however, the decline in the allocation to equities is sharper in 2004. During 2000-2005, US companies had a relatively stable allocation to equities and bonds, however, we observe a decline in the allocation to equities in the period 2005-2007. ${ }^{11}$

\section{(Table 2 about here)}

Figure 1 depicts the mean percentage of pension assets allocated to equity and debt securities for UK and US companies (Figure 1a) and for UK early adopters of FRS 17 (Figure 1b). Figure 1a shows a gradual decrease (increase) in the allocation to equities

\footnotetext{
${ }^{10}$ All continuous explanatory variables are winsorized at $1 \%$ and $99 \%$ to mitigate the effect of extreme observations, except $T A X R_{i t}$ and $D I V P_{i t}$ which are winsorized at $5 \%$ and $95 \%$ to remove negative values.

${ }^{11}$ We also examined changes in asset allocation using market values of stocks and bond that existed in 2000. This way, we attempt to remove the effects of market value changes on the composition of pension assets and isolate the effect of corporate rebalancing. The decline in the allocation to stocks and the increase in the allocation to bonds are more transparent in both sub-samples.
} 
(bonds) in UK companies during the sample period. The average allocation in US companies, on the other hand, is not as monotonic. Until 2003, US companies maintained a relatively stable allocation to equities. Between 2003 and 2005, average allocation to equities increased due to higher stock prices. From 2005 to 2007 we observe a significant decrease in the allocation to equity in US companies.

Figure 1b, which focuses on early adopters of $F R S 17$, shows a gradual decrease (increase) in the allocation to equities (bonds). However, we observe a sharp decline in the allocation to equities in 2001, the year FRS 17 was released. Overall, early adopters exhibit a more conservative asset allocation relative to other UK companies.

(Figure 1 about here)

Figure 2 depicts the trend of pension asset allocation around the adoption of FRS 17/ $I A S 19$ in the UK (Figure 2a), SFAS 158 in the US (Figure 2b) and early adopters of FRS 17 (Figure 2c). For each company, we identify the adoption year and denote it as AY(0). Then, we plot mean percentage of pension assets allocated to equities and bonds around the adoption year. Figure 2a presents information for the entire UK sample between AY(-3) and $A Y(+2)$. The figure exhibits a decline in pension funds invested in equities, and an upward trend in the percentage invested in bonds. These changes are more transparent in years $\mathrm{AY}(+1)$ and $\mathrm{AY}(+2)$, consistent with our argument that the new accounting standard caused UK companies to transfer pension assets from equities to bonds.

Figure 2b presents information for US companies between AY(-3) and AY $(+1) .{ }^{12}$ The figure also exhibits a decline in pension funds invested in equities and an upward trend in the percentage invested in bonds subsequent to adoption of $S F A S 158$. However, these changes are not as sharp as in the UK. Figure 2c present movements in asset allocation for UK early

\footnotetext{
${ }^{12} \mathrm{AY}(+2)$ is fiscal 2008 and thus unavailable at this time.
} 
adopters. As in Figure 2a, we observe sharp declines in the allocation to equities around the adoption of the new standard.

(Figure 2 about here)

\section{Empirical Results}

Table 3, Panel A, provides results for testing whether UK companies changed their pension asset allocation during the Disclosure period of FRS 17 (Hypothesis 1). The results show that UK companies increased (decreased) their allocation to bonds (equities) during the Disclosure period (at the 0.01 level). In particular, average allocation to bonds increased by 5.4\% (significant at the 0.01 level) while average allocation to equities decreased by $4.3 \%$ (significant at the 0.01 level). A similar pattern is observed for early adopters of FRS 17 . These companies increased the allocation to bonds by 3.4\% (significant at the 0.02 level) and decreased the allocation to equities by 3.6\% (significant at the 0.02 level).

For comparison, we measured the changes in asset allocation in US companies prior to the adoption of $S F A S 158$. We find that US companies decreased the allocation to bonds by $3 \%$ and increased the allocation to equities by $5 \%$ (these changes are significant at the 0.01 level). The results in Table 3, Panel A, support Hypothesis 1 - UK companies decreased their exposure to equities during the disclosure period of $F R S 17$.

Panel B of Table 3 presents results for testing whether UK and US companies changed their pension asset allocation during the adoption of full pension recognition under IAS 19/ FRS 17 in the UK and SFAS 158 in the US (Hypothesis 2). The test statistic is constructed as the difference between $\%$ Equity (and $\%$ Bond) in the pre-adoption and the post-adoption year $(-1,+1)$

On average, UK companies increased their allocation to bonds by 3.7\% and decreased the allocation to equities by $4.6 \%$ around the adoption of Full Recognition under FRS 17 / 
IAS 19 (both changes are significant at the 0.01 level). The change in asset allocation is more extreme in early adopters of FRS 17. This sub-sample of companies increased the allocation to bonds by $4.8 \%$ and decreased the allocation to equities by $6.6 \%$ (both changes are significant at the 0.01 level). A change in asset allocation is also observed in US companies around the adoption of SFAS 158. In particular, US companies increased the average allocation to bonds by $2.5 \%$ and decreased the average allocation to equities by $3.9 \%$ (both changes are significant at the 0.01 level).

The results in Panel B of Table 3 support Hypothesis 2. In particular, the evidence suggests that both UK and US companies modified their pension asset allocation policies by shifting pension assets from equity to debt securities. In addition, the magnitude of this shift is, on average, similar in both countries. This shift reduces the effects of full recognition accounting on the balance sheet and comprehensive income.

(Table 3 about here)

While the results in Table 3 support Hypotheses 1 and 2, there could be alternative explanations for the changes in pension asset composition. Prior literature suggests three alternative reasons for changes in pension asset composition: (i) higher funding levels, due to recent regulatory changes, caused companies to shift assets from equities to bonds; (ii) shorter investment horizons prompted companies to shift pension assets from equities to bonds; and (iii) increase in overall firm risk might have caused companies to shift assets from equities to bonds.

To examine the potential effect of funding levels, investment horizon and firm risk on asset allocation, we examine the behaviour of these factors starting three years before adoption of full pension recognition until two year after adoption (one year after adoption for US companies). The results are presented in Table 4. 
As Table 4 shows, average funding levels (FUND) have increased for both UK and US companies around the adoption of the new standards. These increases, which are significant at the 0.01 level, could explain the shift from equities to bonds in UK and US companies. Investment horizons $(H O R)$ increased around the adoption of the new standards in both countries (significant at the 0.01 level). However, an increase in investment horizon is inconsistent with a switch from equities to bonds; thus, changes in investment horizons are unlikely to be the cause for the shift in asset composition. We further examined the proportion of companies that closed their defined benefit plans to new entrants (CLOSE). Closing the fund to new entrants reduces the investment horizon over time and could trigger a shift from equities to bonds. As Table 4 shows, the proportion of closed plans increases in the UK (from 0.51 prior to adoption to 0.60 after adoption) and in the US (from 0.24 prior to adoption to 0.35 after adoption). These increases, which are significant at the 0.01 level, could explain the movement of pension assets from equities to bonds. As for firm risk, we find that mean leverage ( $L E V$ ) decreased over time and mean firm size (SIZE) increased over time in both countries. The reduction in firm risk, as reflected in leverage and size, is inconsistent with the switch of pension assets from equities to bonds, thus cannot serve as a potential explanation for the shift of pension assets from equities to bonds.

The middle panel of Table 4 presents mean variables for UK early adopters. We find that funding levels and firm risk remained relatively stable from three years before adoption until two years after adoption. Investment horizon increased from the year before adoption until the year after adoption (significant at the 0.09 level) and the proportion of closed plans increased from 0.36 to 0.42 around the adoption of FRS 17 (significant at the 0.08 level). Thus, the only alternative explanation to the switch of pension assets from equities to bonds in UK early adopters is the increase in the proportion of closed plans.

(Table 4 about here) 
So far, the results are consistent with the argument that the shift in pension assets in UK and US companies is, at least partially, driven by new accounting standards, although and the increase in the proportion of closed funds and increases in funding levels could also explain the shift from equities to bonds. We now turn to cross-sectional analysis in order to examine these effects in a multivariate setting.

First, we estimate equation 2, in which the dependent variable is the change in the allocation to equities during the Disclosure period (rDISCLOSE) prior to the adoption of FRS 17/IAS 19. As Table 5 shows, the coefficients on the impact variables (EXPOS1 and EXPOS2) are positive, as expected, and significant at the 0.05 level. This result, which supports Hypothesis 3a, suggests that UK companies with larger pension schemes relative to shareholders' equity shift more funds from equities to bonds.

The evidence in Table 5 also highlights the role of other factors in explaining changes in asset allocation during the Disclosure period. Specifically, UK companies that experienced an increase in funding levels over the Disclosure period shifted more assets from equities to bonds, as reflected by positive (significant at the 0.10 level) coefficients on $\triangle F U N D$. In addition, companies that experienced an increase in the investment horizon shifted less assets from equity to debt securities, as reflected by the negative coefficients on $\triangle H O R$ (significant at the 0.05 level). We also find that companies that experienced an increase in effective tax rates $(\triangle T A X)$ shifted more pension assets to bonds, as expected. Furthermore, companies with higher financial leverage $(\triangle L E V)$ shifted more assets to bonds, probably to mitigate the effect of subsequent recognition on the volatility of shareholders' equity. Finally, companies that closed their pension plans to new entrants during the Disclosure period shifted more assets from equities to bonds, as reflected by the positive coefficients on $\triangle C L O S E$ (significant at the 0.01 level). 
The results in Table 5 suggest that during the Disclosure period, UK companies shifted pension assets from equities to bonds because of changes in funding levels, investment horizons, effective tax rates, financial leverage and plan scope. Among these variables, the variable that had the most significant effect on asset allocation is $\triangle C L O S E$. In particular, companies that closed their pension plans to new entrants shifted more funds from equities to bonds. However, after controlling for these effects, we find that UK companies with larger pension plans relative to shareholders' equity shifted more pension assets from equity to debt securities during the FRS 17 Disclosure period. We attribute these findings, which support Hypothesis 3a, to the new disclosure requirements of $F R S$ 17. In particular, these new pension disclosures prompted companies with larger pension plans relative to shareholders' equity to reduce the volatility of more visible and transparent pension deficits.

(Table 5 about here)

To test Hypothesis 3b, we estimate equations (3), which explains the change in the allocation to equity securities during the Full Recognition period of FRS 17/IAS 19 in the UK and SFAS 158 in the US. Table 6 reports results for the UK sample on the left panel and for the US sample on the right panel.

Starting with the UK sample, the coefficients on the main test variables, $\triangle E X P O S 1$ and $\triangle E X P O S 2$, are positive, as expected, and significant at the 0.05 level. This result, which supports Hypothesis 3b, suggests that UK companies with larger pension plans relative to shareholders' equity shifted more assets from equity to debt securities around the adoption of FRS 17/IAS 19.

In addition, the coefficients on $\triangle F U N D$ are negative (significant at the 0.05 level). This result suggests that UK companies that experienced an increase in funding levels shifted less pension assets from equities to bonds. Also, the coefficients on $\triangle T A X R$ are positive (significant at the 0.01 level), as expected, suggesting that companies with higher effective 
tax rates shifted more funds to bonds. Furthermore, the coefficients on $\triangle L E V$ are positive (significant at the 0.05 level), as expected, suggesting that companies with higher debt shifted more fund to bonds to reduce the effect of full recognition on the volatility of shareholders' equity. Finally, the coefficients on $\triangle C L O S E$ are positive, as expected, and significant at the 0.05 level, consistent with the argument that companies that closed their pension plans to new entrants during the adoption period shifted more funds from equities to bonds. Finally, the positive coefficients on $r D I S C L O S E$ suggest that companies that shifted more funds from equities to bonds prior to adoption continued to shift assets to bonds during the adoption period.

Overall, these findings, which support Hypothesis 3b, are consistent with the claim that UK companies with larger pension plans relative to shareholders' equity shifted more pension assets from equity to debt securities during the FRS 17/IAS 19 Full Recognition period incrementally to changes in funding levels, effective tax rates, financial leverage and plan coverage. ${ }^{13}$

Table 6 also presents results for estimating equations (3) using US data (right panel). The coefficients on the main test variables, EXPOS1 and EXPOS2, are positive and significant at the 0.10 level or better, which supports Hypothesis 3b. This result suggests that, similar to UK companies, US companies with larger pension plans relative to shareholders' equity shifted more assets from equity to debt securities during the $S F A S 158$ Full Recognition period.

The results also highlight the role of dividend payout, effective tax rates and financial leverage in asset allocation of US companies. In particular, companies that pay more

\footnotetext{
${ }^{13}$ We also estimated equation (3) for UK early adopters (42 observations with complete data). We find (results not tabulated) positive coefficients on $\triangle E X P O S 1$ and $\triangle E X P O S 2$ (significant at the 0.10 level), as expected, suggesting that early adopters with larger pension plans relative to shareholders' equity shifted more funds from equities to bonds. We also find positive coefficients on $\triangle L E V$ (significant at the 0.10 level), suggesting that companies with larger financial leverage shifted more funds to bonds possibly to reduce the likelihood of violating debt-related covenants.
} 
dividends shifted more funds to bonds to reduce the effect of the new standard on the stability of dividends. Also, as expected, companies with higher effective tax rates and larger financial debt shifted more funds to bonds. In contrast to our results for UK companies, the coefficients on $\triangle F U N D, \triangle C L O S E$ and $r D I S C L O S E$ are not significant in explaining the shift to bonds. Overall, our findings are consistent with the argument that US companies shifted pension assets from equities to bonds to reduce the impact of the new standard on the volatility of shareholders' equity, which in turn reduces the volatility of dividends and the likelihood of violating debt covenants.

(Table 6 about here)

\section{Conclusions}

FRS 17 and the revised IAS 19 radically changed accounting and reporting of defined benefit plans in the UK by initially introducing new market-based pension disclosures and subsequently requiring full balance sheet recognition of the pension surplus/deficit. In December 2006, the $F A S B$ issued $S F A S 158$ replacing the partial recognition method of SFAS 87 with full balance sheet recognition of defined benefit post-retirement plans. To reduce the effect of capital market fluctuations on reported earnings, these standards require that actuarial gains/losses shall be recognized in comprehensive income. We investigate whether new market-based pension disclosures had any impact on pension asset allocation of UK companies. We also examine whether asset allocation of UK and US companies changed around the adoption of the new standards.

We identify a Disclosure period during which UK companies had to disclose all the required data under $F R S 17$ in the notes to the financial statements without formally recognizing the full pension surplus/deficit on the balance sheet. In addition, we identify a Full Recognition period around the adoption of either FRS 17 or IAS 19 in the UK and SFAS 
158 in the US. We hypothesize that there exists a shift from equity to debt securities by UK companies during the Disclosure period of FRS 17 due to the higher visibility of pensions in the UK and the anticipation of full recognition. We also predict a decline in pension funds allocated to equity securities during the Full Recognition period, around the adoption of FRS 17/IAS 19 in the UK and SFAS 158 in the US.

We find that during the FRS 17 Disclosure period UK companies reduced their pension fund exposure to equity securities and at the same time increased their allocation to debt securities. We also find that UK companies decreased their allocation to equities during the FRS 17/IAS 19 Full Recognition period. Similarly, US companies decreased their allocation to equities following the adoption of $S F A S$ 158. Finally, cross-sectional analysis reveals that the shift from equity to debt securities is more pronounced in companies with relatively larger pension schemes.

In our analysis, we also considered alternative explanations to the shift of pension funds from equities to bonds. We find that changes in funding levels that followed new minimum funding requirements are associated with a shift of pension assets from equities to bonds. In addition, many companies in the UK and the US have recently closed their defined benefit plans to new entrants. This modification in plan coverage also explains the shift from equities to bonds, as the average age of the plan participants increases and the investment horizon is shortened. Nevertheless, the potential impact of the new pension accounting standards on the volatility of shareholders' equity incrementally explains the cross-sectional variation in the shift to equities in both the UK and the US around the adoption of the new pension accounting standards. 


\section{REFERENCES}

Accounting Standards Board (ASB). 2000. Financial Reporting Standards (FRS) No. 17, Retirement Benefits. London: ASB.

Amir, E. and S. Benartzi. 1999. "Accounting Recognition and the Determinants of Pension Asset Allocation." Journal of Accounting, Auditing and Finance, vol. 14, pp.321-343.

Amir, E., and A. Ziv. 1997. "Recognition, disclosure or delay: Timing the adoption of SFAS 106." Journal of Accounting Research (Spring): 61-81.

Bader, L. N. 1991. The Financial Executive's Guide to Pension Plans. New York: Salomon Brothers, Inc.

Black, F. 1980. "The Tax Consequences of Long-run Pension Policy." Financial Analysts Journal, vol. 36, pp. 25-31.

Blake, D. 2001. UK Pension Fund Management: How is Asset Allocation Influenced by the Valuation of Liabilities. The Pension Institute Discussion Paper PI-0104.

Bodie, Z., J. O. Light, R. Morck, and R.A. Taggart. 1984. Funding and Asset Allocation in Corporate Pension Plans: An Empirical Investigation. NBER Working Paper No. 1315 (March): Cambridge, MA: National Bureau of Economic Research.

Brewsterin, D. 2005. US Pension Accounting Shift “would Hit Equities”. Financial Times, November 21.

D’Souza, J., J. Jacob, and B.A. Lougee. 2004. Why Do Firms Convert to Cash Balance Pension Plans? An Empirical Investigation. Working Paper, Cornell University.

Feldstein, M., and S. Seligman. 1981. Pension Funding, Share Prices and National Saving. The Journal of Finance 36: 801-824.

Fernandez, F. 2002. There is no Escape from FRS 17. The Treasurer, March 2002: 29-30.

Financial Accounting Standards Board (FASB). 1985. Statement of Financial Accounting Standards (SFAS) No. 87, Employers' accounting for pensions. Norwalk, CT: FASB.

Financial Accounting Standards Board (FASB). 2006. Statement of Financial Accounting Standards (SFAS) No. 158, Employers' accounting for Defined Benefit Pension and Other Postretirement Plans - An Amendment of FASB Statements No. 87, 88, 106 and 132(R). Norwalk, CT: FASB (September).

Friedman, B.M. 1983. Pension Funding, Pension Asset Allocation, and Corporate Finance: Evidence from Individual Company Data. In Financial Aspects of the United States Pension System, edited by Z. Bodie and J.B. Shoven. Chicago: University of Chicago Press: 107-152.

Harris, T.S., L. Michaelides, E.H. Huh and J. van Bezooyen. 2001. Into the UK Pension Pit. Valuation and Accounting (November $21^{\text {st }}$ ): Morgan Stanley. 
Harrison, J.M., and W.F. Sharpe. 1983. Optimal Funding and Asset Allocation Rules for Defined Benefit Pension Plans. In Financial Aspects of the United States Pension System, edited by Z. Bodie and J.B. Shoven. Chicago: University of Chicago Press: 91106.

International Accounting Standards Board (IASB). 2004. International Accounting Standards (IAS) No. 19, Employee Benefits (Revised December 2004). London: IASB.

Klumpes, P., and M. Whittington. 2003. The Impact of UK Accounting Rule Changes on Pension Terminations, Working Paper, University of Warwick.

McLeish, N. 2001. Boots Pension Fund Switch Boosts Sterling Capital Markets. EuroWeek, November 2.

McSherry, M. 2006. More Firms may End Defined Benefit Pensions. Reuters News, April 11.

Petersen, M.A. 2008. Estimating Standard Errors in Finance Panel Data Sets: Comparing Approaches. Review of Financial Studies, forthcoming.

Ralfe, J. 2002. Why Move to Bonds? The Actuary, March, pp. 28-29.

Reynolds, B. 2002. FTSE100 Pension Funds are £25bn in Deficit, Leading Actuary Condemns Continued Confusion from FRS 17 Volatility. Accountancy, August 5.

Swinkels, L. 2006. "Does the Introduction of IFRS Lead to Defined Contribution Pension Schemes? Working Paper, Erasmus University, The Netherlands (September).

Tepper, I. 1981. Taxation and Corporate Pension Policy. Journal of Finance 36: 1-14. 
Figure 1

Mean percentage of pension assets allocated to equity securities and bonds for UK and US sponsoring companies during 2001-2007.

Figure 1a - UK and US Companies

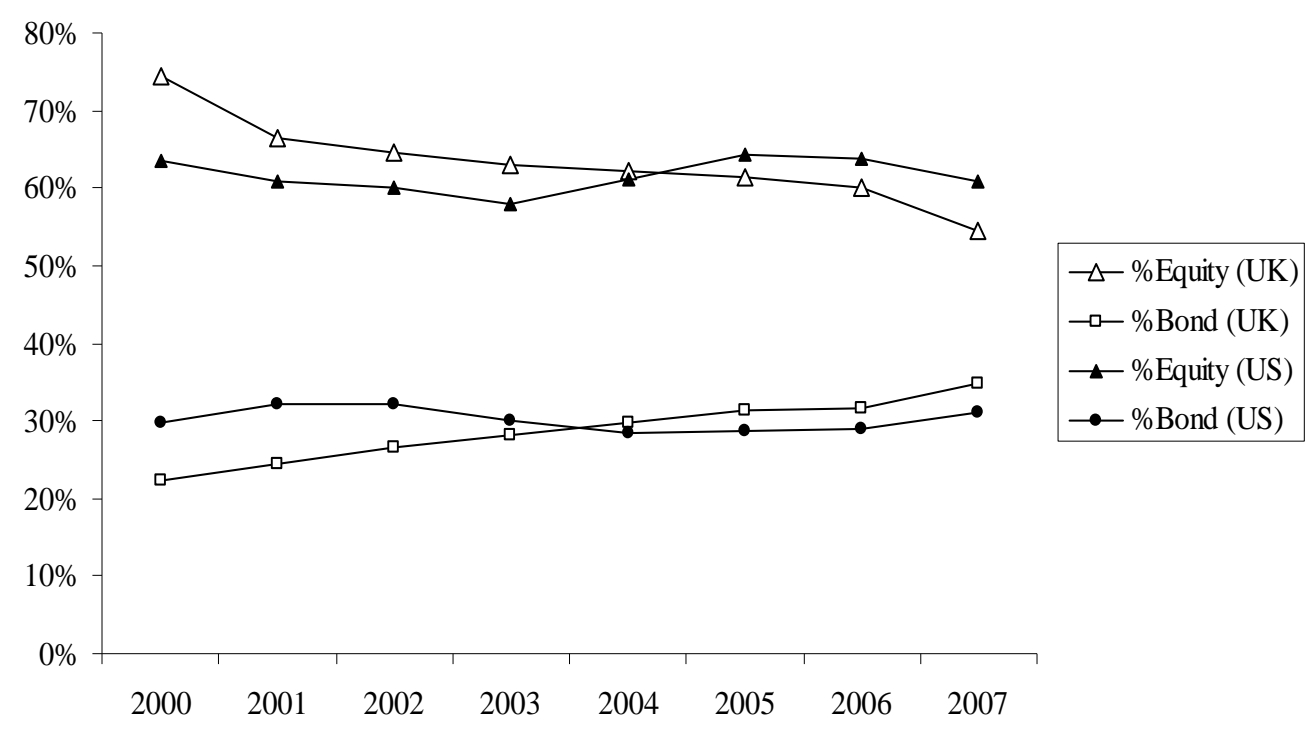

Figure 1b - UK Early Adopters of FRS 17

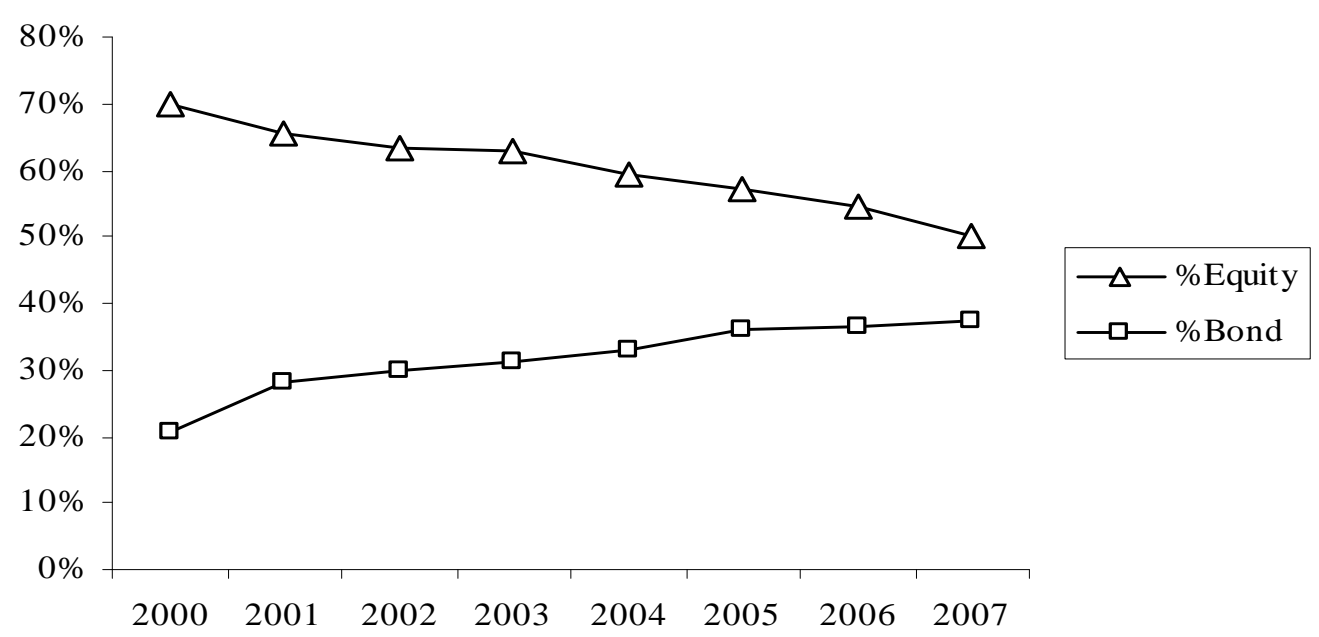


Figure 2

Pension Asset Allocation around the Adoption of Full Pension Recognition*

(FRS 17/ IAS 19 in the UK; SFAS 158 in the US)
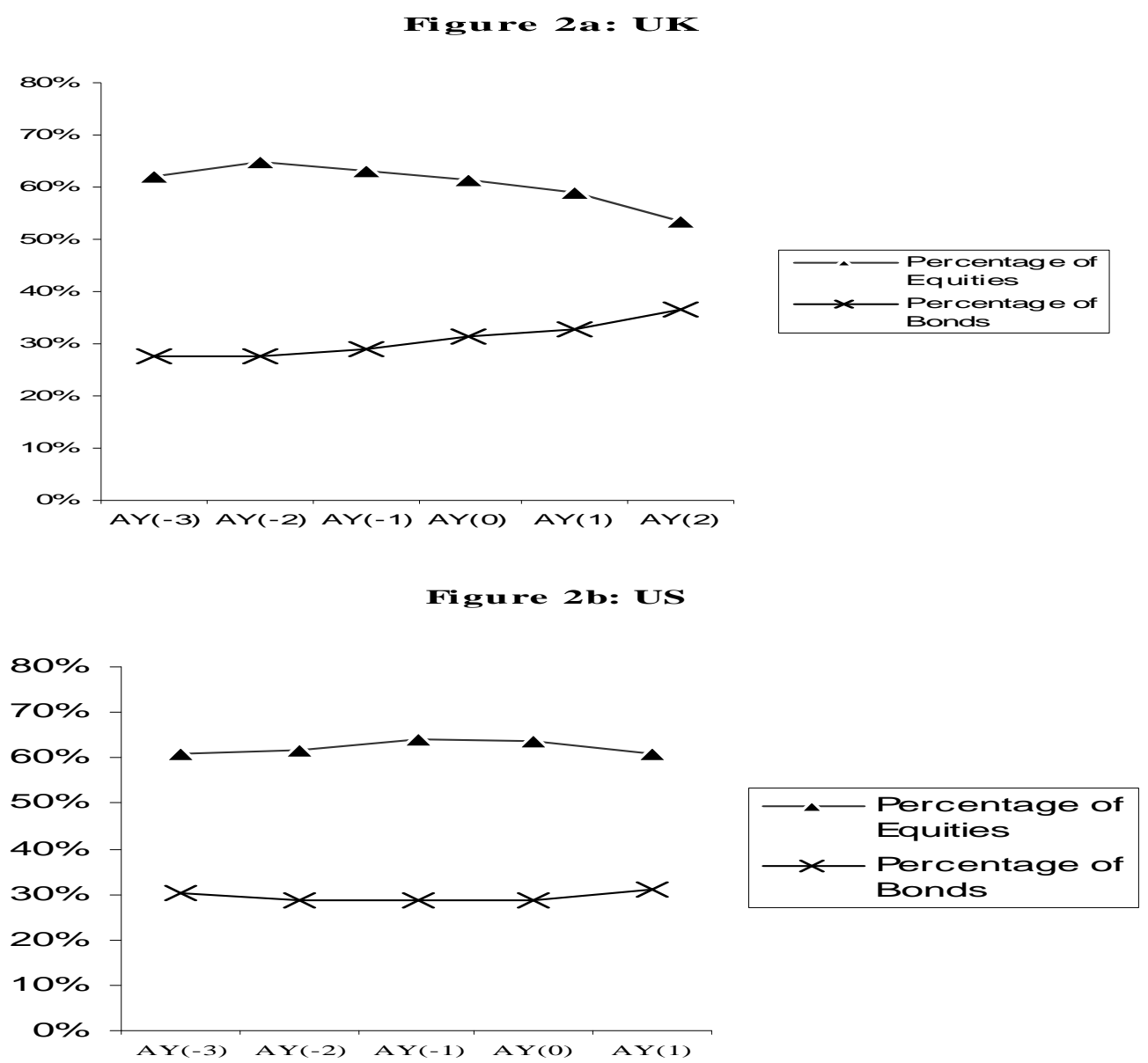

Figure 2c: UK Early adopters

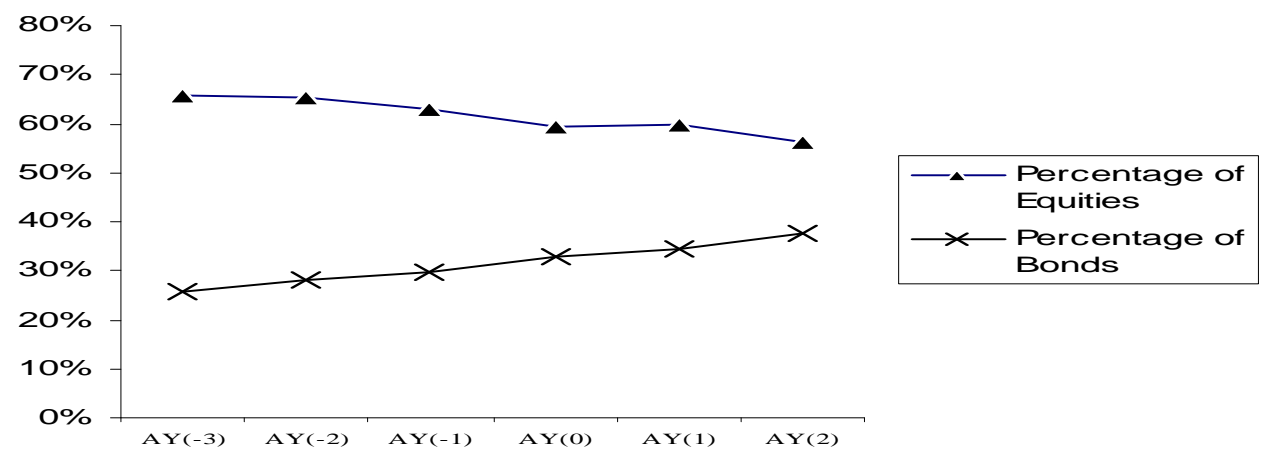

*Note: The upper figure presents allocation for the entire UK sample. The middle figure presents information for the entire US sample. The lower figure presents the pension asset allocation for UK early adopters around the adoption of $F R S 17$. Ay(0) denotes the year of adoption. 
Table 1

Descriptive Statistics for UK and US Companies over 2001-2007*

\begin{tabular}{l|ccc|ccc}
\hline & \multicolumn{3}{|c|}{ UK Sample } & \multicolumn{3}{c}{ US Sample } \\
Variable & Mean & Median & STD & Mean & Median & STD \\
\hline rEQUITY & 0.62 & 0.64 & 0.17 & 0.62 & 0.64 & 0.14 \\
EXPOS1 & 1.06 & 0.50 & 1.42 & 0.80 & 0.46 & 0.92 \\
EXPOS2 & 1.23 & 0.61 & 1.66 & 0.89 & 0.50 & 1.03 \\
FUND & 0.99 & 0.99 & 0.18 & 0.97 & 0.95 & 0.19 \\
HOR & 3.81 & 3.76 & 0.51 & 3.72 & 3.70 & 0.46 \\
LEV & 0.22 & 0.21 & 0.17 & 0.27 & 0.23 & 0.20 \\
DIVP & 0.09 & 0.09 & 0.12 & 0.09 & 0.06 & 0.11 \\
TAXR & 0.31 & 0.30 & 0.11 & 0.32 & 0.34 & 0.10 \\
SDCF & 0.15 & 0.05 & 0.24 & 0.09 & 0.05 & 0.11 \\
SIZE & 7.98 & 7.72 & 1.26 & 8.96 & 8.95 & 1.52 \\
CLOSE & 0.47 & 0.00 & 0.50 & 0.12 & 0.00 & 0.33 \\
\hline
\end{tabular}

*Note: The Table presents variable descriptive statistics for samples of UK (1,509 firm/year observations) and US (2,128 firm/year observations) large companies that sponsor defined benefit pension plans and for which financial and pension asset allocation data were available during the period 2001-2007. Variables are defined as follows: rEQUITY - The ratio of pension assets allocated to equity securities over the fair value of total pension assets at fiscal year end. EXPOS1 - Fair value of pension assets divided by shareholders' equity at fiscal year end. Shareholders' equity is adjusted by undoing the recognition of actuarial gains/losses and the recognition of net pension surplus/deficit. EXPOS2 - Projected benefit obligation $(P B O)$ divided by shareholders' equity at fiscal year end. Shareholders' equity is adjusted by undoing the recognition of actuarial gains/losses and the recognition of net pension surplus/deficit. FUND - Funding ratio, measured as fair value of pension assets divided by the accumulated benefit obligation $(A B O)$ at fiscal year end. For UK firms, we approximate $A B O$ as $A B O=P B O /(1+G)^{N}$, where $G$ is the assumed salary growth rate and $N$ is the pension investment horizon $(H O R)$. HOR - Investment horizon, measured as the natural logarithm of the projected benefit obligation $(P B O)$ over current service cost. $\mathbf{L E V}$ Financial leverage, measured as long term debt divided by the sum of long term debt and market value of equity. DIVP - Dividend payout ratio, measured as dividends per share divided by retained earnings per share. If retained earnings are negative, we use the average dividends over the current and past two years divided by average retained earnings over the current and past two years. TAXR - Effective tax rate, measured as total tax expense over pre-tax income. If current pre-tax income is negative, then it is measured as the average tax expense over the current and past two years divided by the average pre-tax income over the current and past two years. SDCF - The standard deviation of earnings before extraordinary items over the preceding 5 years, deflated by the book value of equity at fiscal year end. $\boldsymbol{S I Z E}$ - The natural logarithm of market value of equity at fiscal year end. $\boldsymbol{C L O S E}$ - "1" if the principal defined benefit plan is closed to new entrants, and zero otherwise. 
Table 2

Composition of Pension Assets by Country, Year and Portfolio Type*

\begin{tabular}{lcccccccc}
\hline $\begin{array}{l}\text { Asset Category } \\
\text { UK Sample }\end{array}$ & $\mathbf{2 0 0 0}$ & $\mathbf{2 0 0 1}$ & $\mathbf{2 0 0 2}$ & $\mathbf{2 0 0 3}$ & $\mathbf{2 0 0 4}$ & $\mathbf{2 0 0 5}$ & $\mathbf{2 0 0 6}$ & $\mathbf{2 0 0 7}$ \\
Observations & 144 & 254 & 243 & 249 & 251 & 239 & 232 & 217 \\
-Equity & $74.4 \%$ & $66.5 \%$ & $64.6 \%$ & $63.1 \%$ & $62.2 \%$ & $61.5 \%$ & $60.0 \%$ & $54.6 \%$ \\
-Bonds & $22.2 \%$ & $24.5 \%$ & $26.7 \%$ & $28.2 \%$ & $29.7 \%$ & $31.4 \%$ & $31.5 \%$ & $34.9 \%$ \\
-Others & $3.4 \%$ & $9.0 \%$ & $8.7 \%$ & $8.7 \%$ & $8.1 \%$ & $7.1 \%$ & $8.5 \%$ & $10.5 \%$
\end{tabular}

UK Early Adopters

Observations

$\begin{array}{rrrrrrrr}21 & 38 & 54 & 54 & 53 & 49 & 47 & 42 \\ 70.0 \% & 65.6 \% & 63.3 \% & 62.8 \% & 59.5 \% & 57.3 \% & 54.7 \% & 50.2 \% \\ 20.8 \% & 28.1 \% & 29.9 \% & 31.1 \% & 32.9 \% & 36.1 \% & 36.7 \% & 37.5 \% \\ 9.2 \% & 6.3 \% & 6.8 \% & 6.1 \% & 7.6 \% & 6.6 \% & 8.6 \% & 12.3 \%\end{array}$

\section{US Sample}

Observations

-Equity

$63.5 \% \quad 60.8 \%$

306

303

304

344

368

338

-Bonds

$29.8 \% \quad 32.2 \% \quad 32.1 \% \quad 30.0 \%$

$61.1 \% \quad 64.4 \%$

$63.9 \%$

$60.8 \%$

-Others

$6.7 \% \quad 7.0 \% \quad 7.9 \% \quad 12.0 \%$

$28.4 \%$

$28.6 \% \quad 28.9 \% \quad 31.2 \%$

\begin{tabular}{llllllll}
$6.7 \%$ & $7.0 \%$ & $7.9 \%$ & $12.0 \%$ & $10.5 \%$ & $7.0 \%$ & $7.2 \%$ & $8.0 \%$ \\
\hline
\end{tabular}

* Note: The Table provides information on pension asset allocation of UK and US companies based on contemporaneous market values. The samples contain large US and UK companies that sponsor defined benefit pension plans for which pension asset allocation data were available during 2000-2007. The middle panel contains information on UK early adopters of FRS 17. 
Table 3

Changes in Asset Allocation Prior to and During the Adoption of Full Recognition*

Panel A - Asset allocation changes prior to Adoption

\begin{tabular}{lcccc}
\hline & Obs. & $\begin{array}{c}\text { Year } \\
\mathbf{2 0 0 1}\end{array}$ & $\begin{array}{c}\text { Pre-Adoption } \\
\text { Year }\end{array}$ & $\begin{array}{c}\text { t-test } \\
\text { 2001 vs. Pre- } \\
\text { Adoption }\end{array}$ \\
\hline $\begin{array}{l}\text { UK (entire sample) } \\
\text { \%Bond }\end{array}$ & 214 & $24.5 \%$ & $29.9 \%$ & $-3.27(\mathbf{0 . 0 0})$ \\
\%Equity & 214 & $66.5 \%$ & $62.2 \%$ & $\mathbf{2 . 5 1}(\mathbf{0 . 0 1})$ \\
& & & & \\
UK Early Adopters & & & & \\
\%Bond & 48 & $28.1 \%$ & $31.5 \%$ & $\mathbf{- 2 . 4 2 ( 0 . 0 2 )}$ \\
\%Equity & 48 & $65.6 \%$ & $62.0 \%$ & $\mathbf{2 . 5 9 ( 0 . 0 2 )}$ \\
& & & & \\
US & & & & \\
\%Bond & 252 & $32.0 \%$ & $28.0 \%$ & $\mathbf{5 . 1 4}(\mathbf{0 . 0 0})$ \\
\%Equity & 252 & $60.6 \%$ & $65.1 \%$ & $\mathbf{- 4 . 9 2 ( 0 . 0 0 )}$ \\
\hline
\end{tabular}

Panel B - Asset allocation changes around Adoption

\begin{tabular}{lccccc}
\hline & Obs. & $\begin{array}{c}\text { Year } \\
-\mathbf{1}\end{array}$ & $\begin{array}{c}\text { Year } \\
\mathbf{0}\end{array}$ & $\begin{array}{c}\text { Year } \\
+\mathbf{1}\end{array}$ & $\begin{array}{c}\text { t-test } \\
\mathbf{( - 1 , + 1 )}\end{array}$ \\
\hline $\begin{array}{l}\text { UK (entire sample) } \\
\text { \%Bond }\end{array}$ & 180 & $28.9 \%$ & $31.3 \%$ & $32.6 \%$ & $\mathbf{- 4 . 0 8 ( 0 . 0 0 )}$ \\
\%Equity & 180 & $63.3 \%$ & $61.0 \%$ & $58.7 \%$ & $\mathbf{5 . 9 5 ( 0 . 0 0 )}$ \\
& & & & & \\
UK Early Adopters & & & & & \\
\%Bond & 54 & $29.8 \%$ & $33.0 \%$ & $34.6 \%$ & $\mathbf{- 3 . 6 6 ( 0 . 0 0 )}$ \\
\%Equity & 54 & $62.9 \%$ & $59.6 \%$ & $56.3 \%$ & $\mathbf{3 . 6 5 ( 0 . 0 0 )}$ \\
& & & & & \\
US & & & & & \\
\%Bond & 288 & $28.6 \%$ & $28.5 \%$ & $31.1 \%$ & $\mathbf{- 4 . 5 2 ( 0 . 0 0 )}$ \\
\%Equity & 288 & $64.7 \%$ & $64.3 \%$ & $60.8 \%$ & $\mathbf{7 . 3 7}(\mathbf{0 . 0 0})$ \\
\hline
\end{tabular}

Notes:

1. Panel A presents percentage of assets allocated to equities and bonds in year 2001 and the year prior to the adoption of full pension recognition (FRS 17/ IAS 19 in the UK; $S F A S 158$ in the US). The $t$-tests (and corresponding $p$-values) are for the difference between allocation in pre-adoption year and allocation in 2001.

2. Panel B presents percentage of assets allocated to equities and bonds around the adoption of Full Recognition. Year 0 is the year of adoption of FRS 17/IAS 19 in the UK and $S F A S 158$ in the US. The $t$-tests (and corresponding $p$-values) are for the difference between allocation in the post-adoption year and allocation in the pre-adoption year. 
Table 4

Mean variables around the adoption of Full Pension Recognition

\begin{tabular}{|c|c|c|c|c|c|c|c|}
\hline Variables & $\begin{array}{l}\text { AY } \\
(-3)\end{array}$ & $\begin{array}{l}\text { AY } \\
(-2)\end{array}$ & $\begin{array}{l}\text { AY } \\
(-1)\end{array}$ & $\begin{array}{c}\text { AY } \\
(0)\end{array}$ & $\begin{array}{l}\text { AY } \\
(+1)\end{array}$ & $\begin{array}{l}\text { AY } \\
(+2)\end{array}$ & $\begin{array}{c}\text { t-test } \\
(-1,+1)\end{array}$ \\
\hline \multicolumn{8}{|c|}{ UK Full Sample } \\
\hline$F U N D$ & 0.90 & 0.94 & 0.94 & 0.96 & 1.14 & 1.11 & $3.18(0.00)$ \\
\hline$H O R$ & 3.60 & 3.67 & 3.77 & 3.92 & 4.00 & 4.01 & $3.88(0.00)$ \\
\hline CLOSE & 0.47 & 0.48 & 0.51 & 0.59 & 0.60 & 0.60 & $3.00(0.00)$ \\
\hline$S D C F$ & 0.16 & 0.16 & 0.28 & 0.32 & 0.21 & 0.22 & $-0.98(0.33)$ \\
\hline$L E V$ & 0.23 & 0.25 & 0.24 & 0.23 & 0.22 & 0.22 & $-2.35(0.02)$ \\
\hline SIZE & 7.77 & 7.81 & 7.96 & 8.06 & 8.27 & 8.50 & $9.76(0.00)$ \\
\hline \multicolumn{8}{|c|}{ UK Early Adopters } \\
\hline FUND & 1.14 & 1.05 & 0.97 & 0.97 & 0.99 & 1.03 & $1.03(0.31)$ \\
\hline HOR & 3.84 & 3.76 & 3.83 & 4.02 & 4.05 & 4.09 & $1.73(0.09)$ \\
\hline CLOSE & 0.21 & 0.34 & 0.36 & 0.40 & 0.42 & 0.55 & $1.78(0.08)$ \\
\hline$S D C F$ & 0.21 & 0.29 & 0.23 & 0.45 & 0.47 & 0.49 & $1.42(0.17)$ \\
\hline$L E V$ & 0.16 & 0.18 & 0.23 & 0.23 & 0.25 & 0.23 & $0.49(0.63)$ \\
\hline SIZE & 8.24 & 8.19 & 8.17 & 8.14 & 8.29 & 8.43 & $0.63(0.54)$ \\
\hline \multicolumn{8}{|c|}{ US Full Sample } \\
\hline$F U N D$ & 0.93 & 0.95 & 0.95 & 1.07 & 1.12 & NA & $4.71(0.00)$ \\
\hline$H O R$ & 3.74 & 3.73 & 3.76 & 3.81 & 3.86 & NA & $1.80(0.07)$ \\
\hline CLOSE & 0.06 & 0.11 & 0.24 & 0.26 & 0.35 & NA & $3.14(0.00)$ \\
\hline$S D C F$ & 0.10 & 0.11 & 0.17 & 0.13 & 0.18 & NA & $0.27(0.79)$ \\
\hline$L E V$ & 0.28 & 0.25 & 0.25 & 0.24 & 0.24 & NA & $-1.89(0.06)$ \\
\hline SIZE & 9.03 & 9.19 & 9.09 & 9.24 & 9.25 & NA & $5.26(0.00)$ \\
\hline
\end{tabular}

* Note: Mean variables around the adoption of Full Recognition pension accounting. We report $t$-tests (and $p$-values) of differences between the variable in the post-adoption year $(\mathrm{AY}+1)$ and the pre-adoption year (AY -1). Variables are defined in Table 1. Data for US companies for year AY +2 (Fiscal 2008) is unavailable. 
Table 5

Cross Sectional Analysis of Changes in Assets Allocated to Equity Securities in UK

Companies during the Disclosure of Pension Information under FRS 17

\begin{tabular}{|c|c|c|c|}
\hline Variable & Sign & Model 1 & Model 2 \\
\hline$\triangle E X P O S 1$ & + & $\begin{array}{c}0.04 \\
(2.09)^{* *}\end{array}$ & \\
\hline$\triangle E X P O S 2$ & + & & $\begin{array}{c}0.03 \\
(1.94)^{* *}\end{array}$ \\
\hline$\Delta F U N D$ & $?$ & $\begin{array}{c}0.18 \\
(1.81)+\end{array}$ & $\begin{array}{c}0.21 \\
(1.65)+\end{array}$ \\
\hline$\Delta F U N D^{2}$ & $?$ & $\begin{array}{c}0.05 \\
(0.64)\end{array}$ & $\begin{array}{c}0.06 \\
(0.70)\end{array}$ \\
\hline$\triangle H O R$ & - & $\begin{array}{c}-0.14 \\
(-2.22)^{* *}\end{array}$ & $\begin{array}{c}-0.13 \\
(-2.09)^{* *}\end{array}$ \\
\hline$\Delta L E V$ & + & $\begin{array}{c}0.26 \\
(9.50) *\end{array}$ & $\begin{array}{c}0.26 \\
(9.82) *\end{array}$ \\
\hline$\triangle D I V P$ & + & $\begin{array}{c}0.04 \\
(0.42)\end{array}$ & $\begin{array}{c}0.04 \\
(0.44)\end{array}$ \\
\hline$\triangle T A X R$ & + & $\begin{array}{c}0.16 \\
(4.31)^{*}\end{array}$ & $\begin{array}{c}0.15 \\
(5.12)^{*}\end{array}$ \\
\hline$\triangle S D C F$ & + & $\begin{array}{c}0.01 \\
(0.06)\end{array}$ & $\begin{array}{c}0.00 \\
(0.01)\end{array}$ \\
\hline$\Delta S I Z E$ & - & $\begin{array}{c}0.02 \\
(1.09)\end{array}$ & $\begin{array}{c}0.02 \\
(1.08)\end{array}$ \\
\hline$\triangle C L O S E$ & + & $\begin{array}{c}0.10 \\
(13.87)^{*}\end{array}$ & $\begin{array}{c}0.10 \\
(14.20)^{*}\end{array}$ \\
\hline Constant & $?$ & $\begin{array}{c}0.04 \\
(1.36)\end{array}$ & $\begin{array}{c}0.04 \\
(1.31)\end{array}$ \\
\hline $\begin{array}{l}\text { Observations } \\
\text { Adj. } \mathrm{R}^{2}\end{array}$ & & $\begin{array}{l}156 \\
0.19\end{array}$ & $\begin{array}{l}156 \\
0.19\end{array}$ \\
\hline
\end{tabular}

Notes:

1. The Table provides results for estimating Equations (2) for a sample of UK companies that sponsor defined benefit pension plans and for which financial and pension asset allocation data are available. The dependent variable is $r D I S C L O S E$, which is the change in the percentage of assets allocated to equity securities from fiscal 2001until one year prior to adoption of FRS 17/IAS 19, rDISCLOSE = rEQUITY (year 2001) - rEQUITY (Pre-Adoption year), where $r E Q U I T Y$ is the ratio of pension assets allocated to equity securities divided by total pension assets.

2. The model is:

$$
\begin{aligned}
& r D I S C L O S E_{i t}=\beta_{0}+\beta_{1} \Delta I M P A C T_{i t}+\beta_{2} \Delta F U N D_{i t}+\beta_{3} \Delta F U N D_{i t}^{2}+\beta_{4} \Delta H O R_{i t}+\beta_{5} \Delta L E V_{i t} \\
& +\beta_{6} \Delta D I V P_{i t}+\beta_{7} \Delta T A X R_{i t}+\beta_{8} \Delta S D C F_{i t}+\beta_{9} \Delta S I Z E_{i t}+\beta_{10} \Delta C L O S E_{i t}+\varepsilon_{i t}
\end{aligned}
$$

See Table 1 for variable definitions. All independent variables are measured as the difference between year -1 and fiscal 2001. 
3. All standard errors were computed using the Petersen (2008) methodology, which corrects for within company and over time correlations by clustering.

4. *, **, + indicate significance at the $0.01,0.05$, and 0.10 levels, respectively. 
Table 6

Cross Sectional Analysis of the Change in Pension Assets Allocated to Equity Securities around the Adoption of FRS 17/IAS 19 in the UK and SFAS 158 in the US

\begin{tabular}{|c|c|c|c|c|c|}
\hline \multirow[b]{2}{*}{ Variable } & \multirow[b]{2}{*}{ Sign } & \multicolumn{2}{|c|}{ UK Sample } & \multicolumn{2}{|c|}{ US Sample } \\
\hline & & Model 1 & Model 2 & Model 1 & Model 2 \\
\hline$\triangle E X P O S 1$ & + & $\begin{array}{c}0.01 \\
(2.60)^{* *}\end{array}$ & & $\begin{array}{c}0.02 \\
(1.83)+\end{array}$ & \\
\hline$\triangle E X P O S 2$ & + & & $\begin{array}{c}0.01 \\
(2.09)^{* *}\end{array}$ & & $\begin{array}{c}0.01 \\
(2.79)^{*}\end{array}$ \\
\hline$\Delta F U N D$ & $?$ & $\begin{array}{c}-0.76 \\
(-2.02)^{* *}\end{array}$ & $\begin{array}{c}-0.74 \\
(-2.47)^{* *}\end{array}$ & $\begin{array}{c}-0.12 \\
(-0.60)\end{array}$ & $\begin{array}{c}-0.14 \\
(-0.67)\end{array}$ \\
\hline$\Delta F U N D^{2}$ & ? & $\begin{array}{c}0.30 \\
(1.05)\end{array}$ & $\begin{array}{c}0.29 \\
(1.05)\end{array}$ & $\begin{array}{l}0.05 \\
(0.71)\end{array}$ & $\begin{array}{l}0.06 \\
(0.79)\end{array}$ \\
\hline$\triangle H O R$ & - & $\begin{array}{c}-0.02 \\
(-0.97)\end{array}$ & $\begin{array}{c}-0.02 \\
(-0.95)\end{array}$ & $\begin{array}{c}-0.04 \\
(-1.62)\end{array}$ & $\begin{array}{c}-0.04 \\
(-1.56)\end{array}$ \\
\hline$\Delta L E V$ & + & $\begin{array}{c}0.10 \\
(\mathbf{1 . 8 0})+\end{array}$ & $\begin{array}{c}\mathbf{0 . 1 0} \\
(\mathbf{1 . 7 7})^{+}\end{array}$ & $\begin{array}{c}0.04 \\
(2.53)^{* *}\end{array}$ & $\begin{array}{c}0.04 \\
(2.52)^{* *}\end{array}$ \\
\hline$\Delta D I V P$ & + & $\begin{array}{c}-0.16 \\
(-0.39)\end{array}$ & $\begin{array}{c}-0.16 \\
(-0.39)\end{array}$ & $\begin{array}{c}0.05 \\
(2.76)^{* *}\end{array}$ & $\begin{array}{c}0.06 \\
(2.78)^{*}\end{array}$ \\
\hline$\triangle T A X R$ & + & $\begin{array}{c}0.13 \\
(4.76)^{*}\end{array}$ & $\begin{array}{c}0.13 \\
(4.49)^{*}\end{array}$ & $\begin{array}{c}0.14 \\
(2.45)^{* *}\end{array}$ & $\begin{array}{c}0.14 \\
(2.36)^{* *}\end{array}$ \\
\hline$\triangle S D C F$ & + & $\begin{array}{c}0.01 \\
(0.13)\end{array}$ & $\begin{array}{c}0.01 \\
(0.19)\end{array}$ & $\begin{array}{c}0.12 \\
(1.41)\end{array}$ & $\begin{array}{c}0.10 \\
(1.22)\end{array}$ \\
\hline$\Delta S I Z E$ & - & $\begin{array}{c}0.03 \\
(1.33)\end{array}$ & $\begin{array}{c}0.03 \\
(1.27)\end{array}$ & $\begin{array}{l}-0.00 \\
(-0.01)\end{array}$ & $\begin{array}{c}-0.00 \\
(-0.10)\end{array}$ \\
\hline$\triangle C L O S E$ & + & $\begin{array}{c}0.01 \\
(2.44)^{* *}\end{array}$ & $\begin{array}{c}0.01 \\
(2.58)^{* *}\end{array}$ & $\begin{array}{c}-0.01 \\
(-0.66)\end{array}$ & $\begin{array}{c}-0.01 \\
(-0.63)\end{array}$ \\
\hline rDISCLOSE & + & $\begin{array}{c}\mathbf{0 . 0 9} \\
(3.57)^{*}\end{array}$ & $\begin{array}{c}0.09 \\
(3.64)^{*}\end{array}$ & $\begin{array}{c}0.03 \\
(0.65)\end{array}$ & $\begin{array}{c}0.04 \\
(0.71)\end{array}$ \\
\hline Constant & ? & $\begin{array}{c}0.02 \\
(1.02)\end{array}$ & $\begin{array}{c}0.02 \\
(1.10)\end{array}$ & $\begin{array}{c}0.04 \\
(3.18)^{*}\end{array}$ & $\begin{array}{c}0.04 \\
(3.09) *\end{array}$ \\
\hline $\begin{array}{l}\text { Observations } \\
\text { Adj. } \mathrm{R}^{2}\end{array}$ & & $\begin{array}{l}137 \\
0.18\end{array}$ & $\begin{array}{l}137 \\
0.18\end{array}$ & $\begin{array}{l}184 \\
0.11\end{array}$ & $\begin{array}{l}184 \\
0.11\end{array}$ \\
\hline
\end{tabular}

Notes:

1. The Table provides results for estimating Equation (3) using a sample of UK and US companies that sponsor defined benefit pension plans. The dependent variable in this table is $r A D O P T$, which is the change in the percentage of assets allocated to equity securities from one year prior to adoption until one year after adoption. $r A D O P T=$ rEQUITY (Pre-Adoption Year) - rEQUITY (Post-Adoption Year), where $r E Q U I T Y$ is the ratio of market value of pension assets allocated to equity securities divided by market value of total pension assets.

2. The model is:

$$
\begin{aligned}
& r A D O P T_{i}=\delta_{0}+\delta_{1} \Delta I M P A C T_{i}+\delta_{2} \Delta F U N D_{i}+\delta_{3} \Delta F U N D_{i}^{2}+\delta_{4} \Delta H O R_{i}+\delta_{5} \Delta L E V_{i} \\
& +\delta_{6} \Delta D I V P_{i}+\delta_{7} \Delta T A X R_{i}+\delta_{8} \Delta S D C F_{i}+\delta_{9} \Delta S I Z E_{i}+\delta_{10} \Delta C L O S E_{i}+\delta_{11} r D I S C L O S E_{i}+\eta_{i}
\end{aligned}
$$


See Table 1 for variable definitions. All independent variables in Equation (3) are measured as the difference between the pre-adoption and the post-adoption year.

3. All standard errors were computed using the Petersen (2008) methodology, which corrects for within company and over time correlations by clustering.

4. ${ }^{*}, * *,+$ indicate significance at the $0.01,0.05$, and 0.10 levels, respectively. 